THE IMAGE OF WOMEN IN CONTEMPORARY SOVIET FICTION 
Also by Sigrid McLaughlin

SCHOPENHAUER IN RUSSLAND: Zur Literarischen Rezeption bei Turgenev 


\title{
The Image of Women in Contemporary Soviet Fiction
}

\section{Selected Short Stories from the USSR}

\author{
Edited and translated by \\ SIGRID McLAUGHLIN \\ Lecturer in Modern Society and Social Thought \\ Stevenson College \\ University of California at Santa Cruz
}

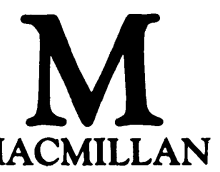


Selection, translation and editorial matter (C) Sigrid McLaughlin 1989

All rights reserved. No reproduction, copy or transmission of this publication may be made without written permission.

No paragraph of this publication may be reproduced, copied or transmitted save with written permission or in accordance with the provisions of the Copyright Act 1956 (as amended), or under the terms of any licence permitting limited copying issued by the Copyright Licensing Agency, 33-4 Alfred Place, London WC1E 7DP.

Any person who does any unauthorized act in relation to this publication may be liable to criminal prosecution and civil claims for damages.

Published by arrangement with the Copyright Agency of the USSR, Moscow

First published 1989

Published by

THE MACMILLAN PRESS LTD

Houndmills, Basingstoke, Hampshire RG21 2XS

and London

Companies and representatives

throughout the world

Typeset by Wessex Typesetters

(Division of The Eastern Press Ltd)

Frome, Somerset

British Library Cataloguing in Publication Data

The image of women in contemporary Soviet

fiction: selected short stories from the

USSR

I. McLaughlin, Sigrid, 1940

$891.73^{\prime} 01^{\prime} 08$ [FS]

ISBN 978-0-333-48723-5

ISBN 978-1-349-20371-0 (eBook)

DOI 10.1007/978-1-349-20371-0 
Nepostizhimy

Tainy perevoda:

Byla parodiya,

A stala oda.

Unfathomable are

The secrets of translation:

There was a parody -

An ode's the new creation.

Byt' zhenshchinoi - chto eto znachit?

Kakoyu tainoyu vladet'?

Vot zhenshchina. No ty nezryachii.

Ni v chem ne vinovat, nezryach!

A zhenshchina sebya naznachit,

Naznachit kak lekarstvo - vrach.

I esli zhenshchina prikhodit,

Sebe edinstvenno verna,

Ona prikhodit - kak prokhodit

Chuma, blokada i voina.

I esli zhenshchina prikhodit

I o sebe zavodit rech',

Ona, kak provod, tok provodit,

Chtob nad toboyu svet zazhet'.

Rimma Kazakova, 1987

What does it mean to be a woman?

What is the secret one must know?

Here is a woman. But you're blind.

And blind, you're innocent, alas!

And she prescribes herself,

Like medicine a doctor.

And when a woman comes,

True to herself alone,

She comes, like pestilence, a blockade,

Or like a war that passes through.

And when a woman comes,

Begins to speak about herself,

She's like a wire, bringing current,

To turn on light above your head. 


\section{Contents}

Acknowledgements

ix

The Translation of Russian Names $\quad \mathbf{x}$

Preface

xi

Introduction

1 I. Grekova

A Summer in the City (1965)

2 Yury Trifonov

Vera and Zoyka (1966)

3 Valentin Rasputin

Vasily and Vasilissa (1967)

4 Lyudmila Petrushevskaya

Nets and Traps (1974)

$5 \quad$ Natalya Baranskaya

The Spell (1976)

6 Irina Raksha

Lambushki (1976)

7 Vasily Belov

Morning Meetings (1977)

8 Anatoly Kim

Cage with a Color TV (1981)

9 Viktoriya Tokareva

The Happiest Day of My Life (The Story of a Precocious Girl) (1980)

Between Heaven and Earth (1985) 
viii Contents

10 Valentina Sidorenko

Marka (1984)

11 Tatyana Tolstaya

Dear Shura (1985)

12 Sergei Zalygin

Women and the NTR (1986)

Glossary

239

Suggestions for Further Reading

246 


\section{Acknowledgements}

I wish to thank Gail Warshofsky Lapidus and Bettina Aptheker for their encouragement with this anthology. Numerous individuals have helped to give it its present shape: Alexander Podossinov, Tatyana Patera, Boris Keyser and Roza Sakwa helped clarify Russian meanings, and Merike Beecher, Carol Chittenden, Karen Johnson and Janice Robinson read drafts of the translations and commented on the English. Barbara Heldt helped with the Introduction.

I am grateful to Alma Law for letting me use her translation of Lyudmila Petrushevskaya's 'Nets and Traps', and to Tracy Kuehn for her translation of Irina Raksha's 'Lambushki'. The Committee on Research of the University of California, Santa Cruz, provided generous financial support for typing, xeroxing and editorial help.

Valentin Rasputin's 'Vasily and Vasilissa' was first published, in a slightly different form, in Soviet Literature, no. 3 (1980), translated by Susan Henderson. 


\section{The Translation of Russian Names}

Most Russian names have been left in their Russian form in order to convey to the reader the variety of emotional relationships the speaker expresses through the variations of the basic form of a Russian name. Formally, Russian names consist of first name, patronymic $^{*}$ and last name. The patronymic is the only part of the name that deviates from the Western pattern. It is based on the father's name, to which the ending -ovna for a woman, or -ovich for a man, is appended, meaning 'daughter of' or 'son of'. For example, Valentina Stepanovna of Grekova's story is the daughter of Stepan.

The use of first name and patronymic implies a polite and friendly relationship of strangers and acquaintances. Referring to a person by the patronymic alone reflects a casual, even impolite attitude. If only the last name is employed, distance or formality is implied. The use of the first name alone indicates closeness. Trifonov establishes a subtle hierarchy in his story 'Vera and Zoyka' when he has his narrator refer to the two women of the title exclusively by their first names, and to their employer more formally by first name and patronymic.

Various forms of the first name reveal the emotional relationship of the speaker to the addressed person. The name Valentina allows the endearing abbreviation 'Valya', from which further endearing variations, 'Valyunchik', 'Valyusha' or 'Valechka', are derived that indicate fondness, tenderness and warmth. The ending $-k a$ or $-i k$ indicates familiarity. At times an endearing form is not obvious, because it sounds very different from the original name: 'Shura', for 'Aleksandra', is an example. 


\section{Preface}

This collection of stories grew from an interest in the situation of women in the Soviet Union and from a concern over our inadequate information about the heterogeneity of Soviet life. Animosity to Soviet ideology and government, and outdated notions of Soviet 'totalitarian' society and of the artistic inferiority of its literature have made us focus on dissident and émigré writers whose works are eagerly translated into English, often because of their political agenda. Thus, the moderate number of Soviet literary works that have reached the West in the last decade or two fail to get the publicity a work on camp or prison experiences might muster. But much of the literature published in the USSR has been not only of good quality, but also of general human interest. If we continue to avoid encounters with current Soviet literature, we shut out a major path toward understanding a major other society.

This collection expands the scope of information about Soviet society by offering a variety of stories, all published in the USSR, that touch on a wide range of themes relating to women: work, the family, customs and beliefs, generational problems, leisure, urbanization, rural life, education, social mobility. Offering literary works for extra-literary purposes is not to imply that literary art is an unproblematical means of knowing the world, nor is it to suggest that simple 'mirror' theories of art are valid. The point is simply that official fiction, at its best, is vital and challenging and provides valuable glimpses of the lives lived in a vastly different country.

The collection focuses on the lives of women, because a growing number of English-speaking women are eager to compare their experiences with those of their counterparts in other countries. Such comparison enhances their self-understanding and helps to set off their own achievements and goals. A focus on women also allows the reader to witness the lives of women in a country that has legislated political and social equality since 1917. Has this legislation led to real equality? Are Soviet women emancipated? What does the concept mean to them? How do they juggle career, family and self? What are their needs, their aspirations? How do they see themselves? 
The heroines of the stories are women of various ages, educational backgrounds and careers, and they are caught up in a wide range of situations and activities. They search for their identity and independence, try to cope with their dual roles or with single motherhood, experience love and loneliness, adultery and physical hardship, undergo abortions and divorce, rear their children or refuse to have any, and interact with their parents and in-laws. In the process, the stories reveal a number of circumstances mostly unfamiliar to people in the West, but important for an understanding of the contemporary Soviet mentality: the material and demographic consequences of the Second World War (poverty, hunger, single-mother families); the closeness of family ties; the material difficulties of daily life.

While the literary scholar will be offered a sampling of aesthetically interesting works, the sociologist, political scientist and historian will find material that illustrates some of the attitudes and values, thought patterns and expectations of the Soviet people. It is noteworthy that, in the USSR itself, literature is studied for sociological purposes, as the publication in 1984 of a collection entitled Literature and Sociology (ed. Vladimir Kantorovich and Yuri Kuz'menko) indicates; and many sociological studies, in turn, appear in literary weeklies and monthlies: Literaturnaya gazeta and Novy mir, Voprosy literatury and Literaturnoe obozrenie. In the United States Vera Dunham has pioneered such a use of literature in her pathbreaking book In Stalin's Time.

The stories chosen for this anthology are representative of both men and women authors, so that the reader can ponder whether the stories reflect a female or male consciousness and rhetoric, and in what that might consist. Such selection also raises the question of the different images women and men might create of women. Furthermore, the authors belong to different generations and schools of writing. Some, at around fifty years, are by Soviet standards relatively young: Belov, Kim, Petrushevskaya, Raksha, Rasputin, Tokareva. Two are even younger: Sidorenko and Tolstaya. Of older writers, Trifonov (who died in 1981), Baranskaya, Grekova and Zalygin are represented. The male writers are considered well-established major literary figures. Of the women, Grekova and Baranskaya, now in their late seventies, are widely known as the doyennes of women's writing. Petrushevskaya, mostly famous as a playwright, is beginning to get her hitherto unpublishable stories into print. Tolstaya is the latest rave of 
Moscow literary critics and, with Petrushevskaya, the most original writer.

Some of the authors - Belov, Rasputin - belong to the school of 'village prose', whose followers are preoccupied with the spiritual impact of urbanization. Others - Trifonov and most women writers - deal with everyday life in urban settings. Some writers Kim, Sidorenko - elude classification. The writers also come from different regions of the Russian Federal Socialist Soviet Republic, although most of them have moved to Moscow. As a result, the settings of the stories vary.

Several criteria influenced the selection of the stories: accessibility to an English-speaking readership, quality, and representativeness (age and orientation of authors, chronology, thematics). The stories are realistic and cover the last twenty years of Soviet experience. Their changing thematic preoccupations and perceptions reflect changes in Soviet society at large, changes in consciousness which go hand in hand with political changes.

Each writer is introduced by a biographical sketch and a list of works and secondary literature in English. The Glossary helps readers to familiarize themselves with idiosyncratic facts about Soviet society that enhance comprehension of the stories, and the list of Suggestions for Further Reading is intended to assist readers to explore the book's topics on their own. Words for which there is an entry in the Glossary are signalled in the text by an asterisk. 